\title{
Breast Cancer: Updates on Current Strategies for Screening, Diagnosis and Implications of Treatment Modalities
}

\author{
Moattar Raza Rizvi ${ }^{1 *}$ and Sumbul Zaidi ${ }^{2}$ \\ ${ }^{1}$ Department of Nursing, Majmaah University, KSA \\ ${ }^{2}$ Department of Medical Laboratories, Majmaah University, KSA
}

Submission: August 02, 2019 , Published: August 30, 2019

*Corresponding author: Moattar Raza Rizvi, Department of Nursing, Majmaah University, KSA

\begin{abstract}
Globally, breast cancer is the most common cancer in women. Both in the developed and developing the world, breast cancer is one of the most frequent grounds of mortality and morbidity among women. In 2008, there were an estimated 1.38 million new cases of breast cancer in women, and over 450,000 deaths from breast cancer reported worldwide. In particular, researchers have been found that for women with breast cancer, the diagnostic phase (shortly after diagnosis and before adjuvant therapy), adjuvant phase (throughout adjuvant chemotherapy and radiation therapy) and initial recovery phase (directly after adjuvant therapy has been completed) is particularly challenging. Throughout these phases, women with breast cancer may experience many symptoms resulting from the primary disease and/or the treatment of the disease. Women with breast cancer have travelled an arduous journey by the time they become symptomatic, endure active treatment, and progress either to survival or death. These women may suffer from numerous symptoms resulting from the primary disease and/or the treatment of the disease. Because of its cost and the need for specialized multimodality infrastructure and human resources, the variability in treatment standards offered to breast cancer patients is even higher than that of screening options.

Keywords: Breast cancer; Cancer stem cells; Risk factors; Chemotherapy; Hormone therapy

Abbreviations: IHC: Immunohistochemistry; AJCC: American Joint Committee on Cancer; ER: Estrogen Receptor; MRI: Magnetic Resonance Imaging; BCT: Breast-Conserving Treatment; SERMs: Selective Estrogen Receptor Modulators; SERDs: Selective Estrogen Receptor DownRegulators
\end{abstract}

\section{Introduction}

Breast cancer is a highly heterogeneous disease from a clinical, genetic and phenotypic point of view. Early cancer detection and improvement in cancer treatments are critical factors in improving breast cancer survival. In recent years, the number of breast cancer treatments has highly increased, and the introduction of a structured breast cancer classification has strengthened the criteria for treatment decisions. However, lack of absolute improvement in patient survival after treatment and tumor relapse [1], suggest that, despite treatment improvements, different patients react in different ways to their treatments. This shows that the criteria used to assign patients to a particular option is not enough and that new strategies should be considered to discriminate between patients that will respond or not to individual treatments.

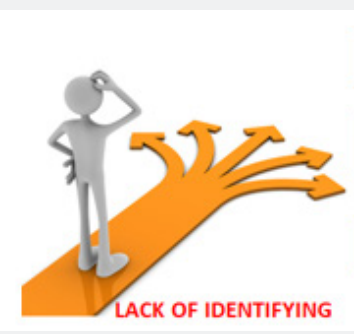

\section{SPECIFIC ETIOLOGY}

PRECISE TIME OF INITIATION

Figure 1: Etiology of Breast cancer. 
Breast cancer is the most common malignancy diagnosed in women and is the leading cause of cancer deaths worldwide [2]. Failure in eradicating breast cancer is primarily due to the lack of identifying a specific etiology, the precise time of initiation and the molecular mechanisms responsible for cancer initiation and progression (Figure 1). Although having a mother or sister with breast cancer significantly increases a woman's risk of developing breast cancer [3], less than $5 \%$ of breast cancer cases can be attributed to the family history of the disease $[4,5]$. This leaves the vast majority of breast cancers as occurring due to environmental effects or unknown genetic factors.

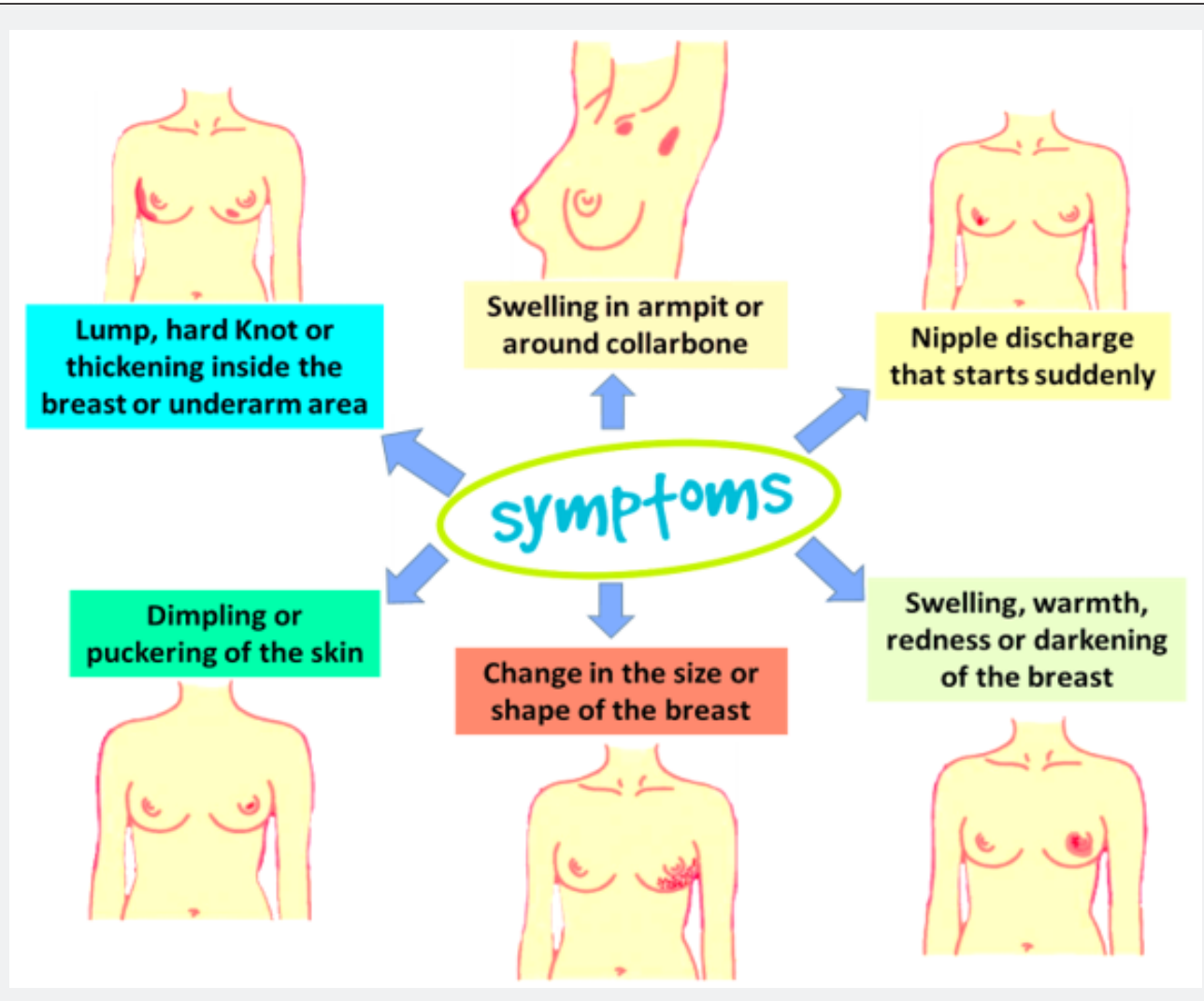

Figure 2: Symptoms associated with the development of breast cancer.

A general limitation in breast cancer research is that the sample usually seems to be taken from women's health or breast cancer centres which may result in only women with an interest or concern in their health being included. Also, there is very little research conducted with women in the 20-25 age group. Most studies that have claimed to include young women usually look at women below 40 (although there is no consistency in age groups between studies). As previously stated, there is no clear definition as to what is meant by the term 'young. Further, it is difficult to ascertain the exact symptoms that a patient with breast cancer may experience (Figure 2). Symptoms can exist alone, however, more often multiple symptoms coincide, and commonalities exist [6]. Indeed patients with cancer often experience several symptoms concurrently [7].

Breast cancers cases present with a wide range of different morphological, biological and clinical characteristics. Different breast cancer subtypes were identified initially by morphological analysis, leading to the classification of carcinomas into ductal or lobular types. At the same time, protein expression analysis by immunohistochemistry (IHC) leads to the identification of different breast cancer subtypes such as the ER-positive or the Her2-positive groups. These parameters are widely used in the clinical setting to assign patients to risk groups to determine their requirement for local and systemic therapy, such as radiotherapy, endocrine and/or chemotherapy, and Her2-targeted therapy.

\section{Risk Factors}

One of the issues when examining breast cancer risk in this light is that, as yet, it is not known exactly what causes breast cancer [8]. An understanding of these risk factors is essential for the development of both treatment and prevention as well as for the identification of women at high risk, for the development of preventative and early detection strategies and for the elimination of adverse environmental conditions and lifestyle behaviours [9]. Several factors have been identified as increasing the risk of breast cancer including age, reproductive or hormonal factors, and family history or genetic factors (Figure 3). 


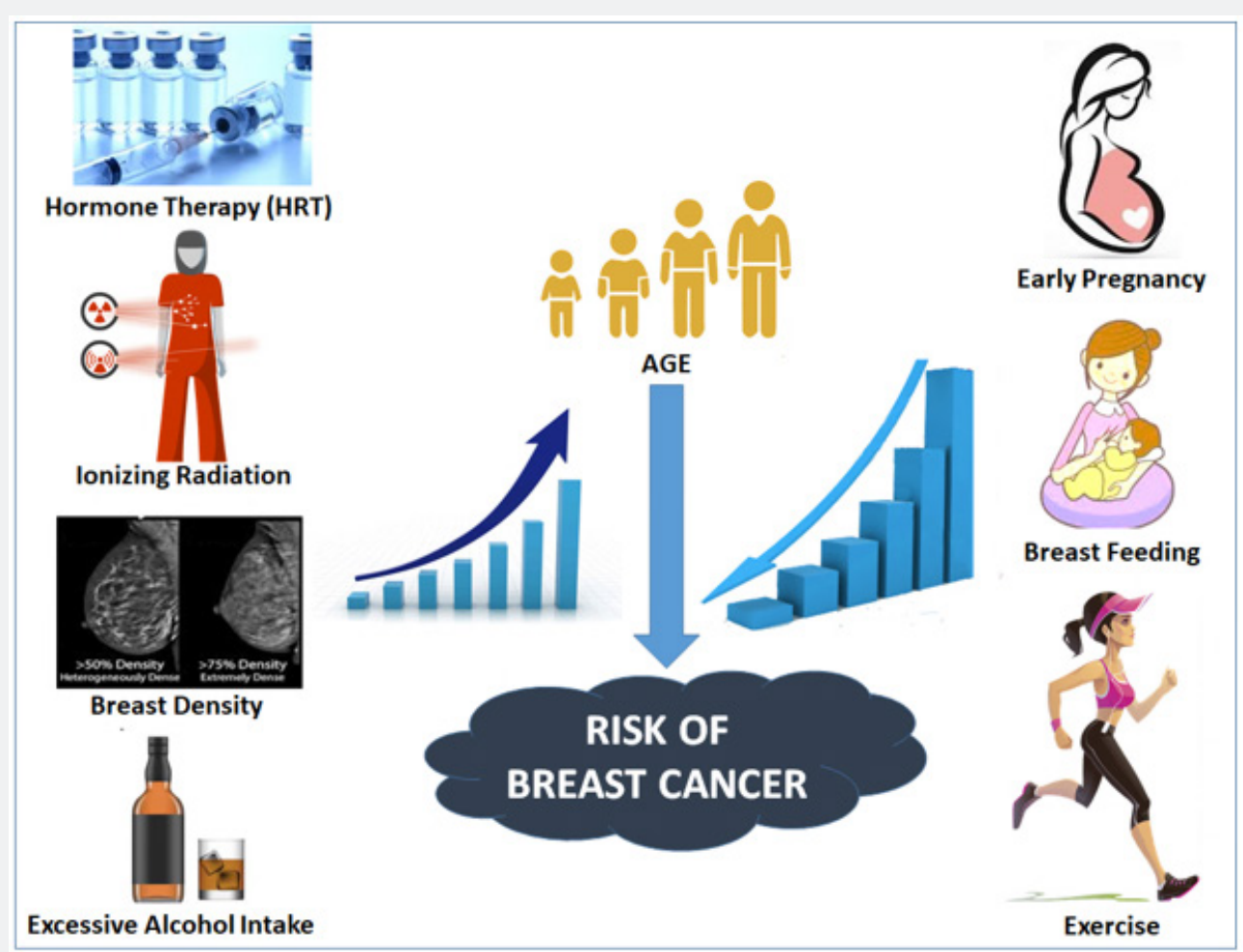

Figure 3: Risk factors associated with the Breast cancer.

Age is one of the strongest and most frequently identified risk factors for breast cancer. As women age, the risk of breast cancer increases [10]. The mortality rates associated with breast cancer increase from 30-34 up to 85 years of age reflecting the risk associated with increased age [1]. Women who have their first menstrual bleed (menarche) early, never bear children (nulliparity) or have menopause later in life have an increased risk of developing breast cancer, due to the increased number of menstrual cycles $[11,12]$. Conversely, women who have their first pregnancy after 30 years of age have an increased risk of developing the disease $[13,14]$.

Family history has been repeatedly acknowledged as a powerful risk factor for the development of breast cancer [1518]. Women who have a first degree relative (mother, sister or daughter) with breast cancer have an increased risk of developing the disease compared to women who have no family history $[9,17]$. This risk becomes even more significant if the relative develops breast cancer before the age of fifty $[8,9,19]$.

Geographical variation has also been viewed as being a risk factor for breast cancer. For women in the western world breast cancer is a regular occurrence; this is not the case for women in other areas of the world such as Eastern Europe, Asia and generally among black populations south of the Sahara [9]. Diet has also been identified as one of the risk factors associated with breast cancer. One of the significant differences seen between countries that have a high incidence of breast cancer and those who have a lower incidence is the consumption of animal fat [9].
A general model for carcinogenesis state that a normal cell must achieve seven new capabilities to become malignant. These changes are a loss of apoptosis, loss of growth inhibition, genetic instability, self-sufficient growth, angiogenesis, limitless replication and tissue invasion capacity.

\section{Breast Cancer Detection and Diagnosis}

Clinical detection of breast cancer is determined through a series of examinations by different methods. Guidelines for diagnosis of breast cancer include using a four-point system with clinical (palpation of the breast and local regional lymph nodes), pathological (core needle biopsy or fine needle aspiration), and radiological examinations (mammography of the breasts and ultrasound of the breast and local regional lymph nodes).

A clinical breast exam is a physical examination of the breast, whereby visual or palpable abnormalities are detected and a patient's history is taken including previous breast screens, changes in the breast or risk factors for developing the disease [20]. A mammogram is an x-ray that can detect the presence or absence of a mass and or microcalcifications or changes in the density of the breast [21]. Ultrasound is used to determine if any masses are solid or a cyst. Mammography together with ultrasound gives increased sensitivity than mammography alone in patients with breast tumors [22]. Magnetic resonance imaging (MRI) is not used routinely in breast cancer screening but is a diagnostic tool available to detect breast tumors in particular cohorts of patients [23]. 
Many breast lesions are found to be benign, and an increased risk of developing breast cancer has been associated only with patients with a family history or highly proliferative lesions [24]. Pathological examination of the lesions determines if they are malignant or not and if so, identifies what type of breast cancer it is. The stage of a tumor is determined based on the American Joint Committee on Cancer (AJCC) TNM staging system which considers the size of the tumor ( $\mathrm{T})$, the involvement of lymph nodes $(\mathrm{N})$ and the presence or absence of metastases (M). Another kind of pathological assessment of grading tumor is Grade IIII or degree of differentiation. Grade I, (Well-differentiated tumors) are organized in the same way as of the tissue of origin having favorable prognosis. However, during tumor evolution, a tumor undergo a reversal of differentiation and lose specialized characteristics resulting in neoplastic tissue that does not look like the tissue of origin (moderately differentiated tumors (Grade II) and poorly differentiated tumors (Grade III, unfavourable prognosis).

The expression of tumour markers is another diagnostic tool used to diagnose breast tumors and determine treatment options. Breast tumours are broadly categorized as luminal
(A or B), Her2 overexpression or triple negative. Luminal breast cancers are positive for either estrogen receptor (ER) or progesterone receptor and negative or positive for human epidermal growth factor receptor 2 (Her2), corresponding to luminal A or B tumors, respectively [25]. Patients with luminal A breast tumors have a better prognosis than those with luminal $\mathrm{B}$ [26]. Her2 postive breast tumors have an increased expression of Her2, as verified by gene expression and protein analysis $[27,28]$. Aberrant expression of Her2 is associated with metastasis [29]. Tumors negative for ER, PR and Her2 are considered triple negative. Triple negative breast tumors are further classified into basal tumors which express basal cytokeratins and epidermal grown factor receptor (EGFR) [30]. Expression of EGFR in breast tumor is associated with an aggressive phenotype and increased lymph node metastasis [31].

\section{Treatment of Breast Cancer}

The treatment of choice depends upon the type of cancer, the stage of disease and the pathologic features observed. The most commonly adopted treatment options (Figure 4) includes the following.

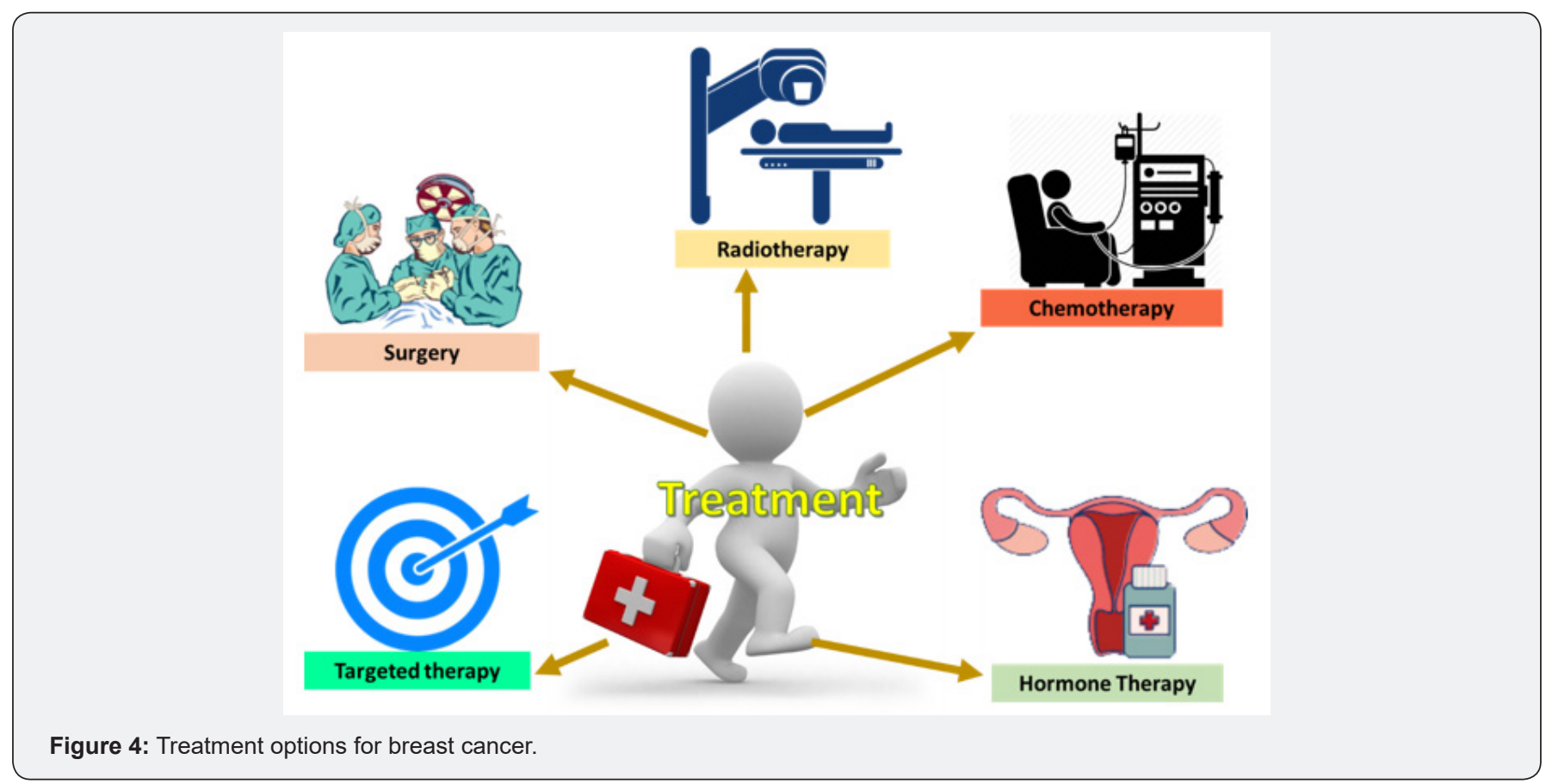

\section{Surgery}

Surgery is the leading treatment option for most breast cancer. A sentinel node biopsy aids the diagnosis of breast cancer and is a procedure whereby a blue dye is injected into the tumor area, and the first lymph node that takes up the dye is removed and checked for the presence of cancer cells, which may indicate metastases [32,33]. Following a diagnosis of breast cancer, surgery is one of the first lines of treatment. Surgery options include a mastectomy or breast-conserving surgery. Although in modified radical mastectomy, the entire tumor mass was removed, failure of this procedure and recurrence of breast cancer was high. A new type of surgical treatment for a lumpectomy is a Breastconserving treatment (BCT) where the tumor and surrounding tissue are removed preserving most of the breast structure [34]. Alternatively, a skin-sparing mastectomy has followed that preserve the skin to allow breast reconstruction $[35,36]$. While overall disease-free survival does not differ between patients who had a total mastectomy or a lumpectomy with or without radiation treatment, disease recurrence following lumpectomy 
has been shown [37]. In particular, patients with triple negative breast cancer have been shown to have increased residual disease after lumpectomy [38]. However, in patients with earlystage breast cancer, a lumpectomy or breast-conserving surgery followed by radiation therapy is as successful as a mastectomy [39-41].

\section{Radiotherapy}

Radiotherapy for treatment of breast cancer used high doses of radiation to kill cancer cells directly and is usually given after surgery. Breast radiation therapy after lumpectomy lowers the rate of local disease recurrence and increases survival [1]. For patients with early breast cancer, when radiotherapy is received after a lumpectomy, its success is comparable to patients who had a mastectomy [37]. Radiotherapy can be given with chemotherapy in most cases, although the therapeutic combinations of chemotherapeutics may lead to adverse toxicity [42]. It is recommended that when radiotherapy is being given with chemotherapy, whether after a mastectomy or breast conserving surgery that it is given after chemotherapy [43]. Patients receiving hormonal therapy can also be given radiotherapy [44]. Side-effects associated with radiotherapy are generally related to the site of treatment and include the skin being tender, red, dry and itchy [45].

\section{Hormone therapy}

Cumulative exposure of the breast epithelium to steroid hormones, particularly estrogens, is a significant risk factor in the development of mammary carcinoma. At least three mechanisms are considered to be responsible for estrogen carcinogenicity. The most widely recognized is the receptor-mediated hormonal activity, which is generally related to stimulation of cellular proliferation, resulting in more opportunities for the accumulation of genetic damage leading to carcinogenesis. The second mechanism is a direct, receptor-independent genotoxic effect elicited by reactive intermediates generated through cytochrome $\mathrm{p} 450$-mediated metabolic activation, which increase DNA mutation rates. Finally, a third mechanism is postulated to compromise the DNA repair system, leading to the accumulation of genetic lesions (such as deletions in chromosomes 9 and 4 essential for tumorigenesis [46].

Hormone receptor positive breast cancers express ER and/or PR. Anti-estrogens such as tamoxifen, fulvestrant and aromatase inhibitors are widely used to treat this type of breast cancer. Treatment occurring before surgery is termed neoadjuvant, and aims to reduce the size of the tumor and stop disease progression $[47,48]$. Treatment following surgery is termed adjuvant. Tamoxifen belongs to a group of drugs known as selective estrogen receptor modulators (SERMs) and works by competitively binding the estrogen receptor thereby blocking its effects $[49,50]$. Treatment with tamoxifen in early breast cancer has been shown to reduce cancer recurrence and mortality (over 15 years) [51]. Fulvestrant is another anti-estrogen belonging to the drug group selective estrogen receptor down-regulators
(SERDs) and has been found to be more effective and have a higher affinity to the ER than tamoxifen [52]. However, in a randomized trial comparing fulvestrant and tamoxifen, tamoxifen showed better efficacy as a first line treatment [53]. Although this fulvestrant has shown effectiveness in the treatment of tamoxifen-resistant breast cancer [54]. Aromatase inhibitors, including anastrozole and letrozole, are another group of antiestrogen drugs that block estrogen synthesis and have been found to have decreased side effects compared to tamoxifen [55-57]. Treatment with tamoxifen or aromatase inhibitors for 5 years has been recommended as a preventive measure for recurrence in patients with hormone receptor positive breast cancer [58].

Some patients with hormone receptor-positive breast cancer, despite treatment with anti-estrogens, develop resistance to treatment. Crosstalk between the ER and others receptors and pathways including Her2, EGFR, insulin-like growth factor receptor (IGF-IR) and PI3K/Akt/mTOR can affect the responsiveness of tumors to anti-estrogen treatment and may lead to resistance $[59,60]$. As such, targeting the ER and other receptors simultaneously has been investigated with positive results and may offer therapies to overcome endocrine resistance $[61,62]$. In particular, a phase III clinical trial treating with the mTOR inhibitor everolimus together with the aromatase inhibitor exemestane improved progression-free survival and response in hormone receptor positive breast cancer patients with advanced disease who had previously received aromatase inhibitors [63]. Based on these the FDA has recently approved the use of everolimus with exemestane in postmenopausal women with hormone receptor positive, Her2 negative breast cancer who have disease recurrence or progression following treatment with aromatase inhibitors [64]. Common side-effects associated with hormone therapy are similar to those experienced by women going through the menopause, and include, hot flushes, vaginal discharge/dryness, nausea, joint and/or muscle pain [65].

\section{Chemotherapy}

Chemotherapy is a treatment option for patients with receptor-negative breast cancer, those who have not responded to endocrine or Her2 targeted treatment and in some cases Her2 positive breast cancer [66]. Chemotherapeutic agents are cytotoxic and target highly proliferative cells. Many chemotherapeutic agents exist that are effective in treating breast cancer and include anti-metabolites, platinum-based agents, anthracyclanes and taxanes to name a few. Some commonly used examples of these agents include 5-fluorouracil, cisplatin, doxorubicin and paclitaxel, respectively [60]. Chemotherapeutic agents are often used in combination or with other targeted therapies.

The use of Herceptin and chemotherapy together has been found to increase survival and decrease disease progression in patients with Her2 positive metastatic breast cancer, than 
those treated with chemotherapy alone [67]. Recently, the use of docetaxel and carboplatin together has been tested in phase II clinical trials for the treatment of later stage breast cancer in women with hormone receptor positive, Her2 positive or triple negative tumors, and was found to have tolerable toxicity levels and good overall response [68]. Additionally, gene expression profiling is being used to predict patient outcome and response to different therapies. Mammaprint $₫$ and Oncotype DX® are two such profiling platforms. In ER-positive breast tumors, the Oncotype DX® based on the expression of cancer-specific genes, predicts whether patients are at risk of cancer recurrence or will benefit from chemotherapy [69].

Chemotherapy targets highly proliferative cells, as such, common side-effects associated with chemotherapy include hair loss, lack of energy and features associated with the digestive system including loss of appetite, nausea, vomiting, diarrhea, mouth ulcers and the blood system including increased susceptibility to infections and bruising due to a compromised immune system [70].

\section{Targeted therapy}

Breast tumors found to overexpress Her2 are treated with the monoclonal antibody Herceptin ${ }^{\circledR}$ (trastuzumab) [27,67]. Aberrant expression of Her2 is associated with decreased survival and worse outcome in breast cancer patients [27]. However, the use of Herceptin ${ }^{\circledR}$ has been shown to improve outcome in patients with metastatic breast cancer alone or in combination with chemotherapy $[63,71]$. Lapatinib, an EGFR and Her2 specific tyrosine kinase inhibitor (TKI), and Herceptin ${ }^{\circledR}$, together with chemotherapy has been found to have increased efficacy in the treatment of Her2 positive breast cancer than with lapatinib or Herceptin ${ }^{\circledR}$ with chemotherapy alone [72]. Side effects associated with Herceptin $\AA$ treatment include nausea, vomiting, hot flushes and joint or muscle pain [73].

\section{Role of Stem Cells and Breast Cancer Stem Cells}

Cancer research has been revolutionized with the identification and characterization of breast cancer stem cells (CSCs) in tumors which may help to improve clinical treatment of cancer. CSCs are enduring, slow-maturing cells that are commonly in a resting, quiescent cell cycle state. Nevertheless, natural breast cancer therapies aim at rapidly dividing cells which may remove the majority of tumor cells, but will most likely not affect CSCs. The greater part of CSCs may be eliminated by surgery, however CSCs have several characteristics which render them resilient to other treatment regimens:

a) CSCs express higher levels of multi-drug resistant proteins (chemotherapy resistant)

b) CSCs express higher levels of reactive oxygen species (ROS) scavenging [74] and DNA damage response genes (radiotherapy resistant) [75]. c) the majority of CSCs do not express the sex hormone receptors, estrogen and progesterone (endocrine therapy resistant). By failing to eliminate CSCs, these long-lived cells will have time to accumulate additional mutations which may promote tumor recurrence and metastasis of the primary tumor.

Only recently, the identification of specific cell markers for mammary stem cell isolation has allowed a better understanding of their behaviour and physiology and promoted the study of mechanisms responsible for the transition from normal to cancer phenotypes [76]. In particular, the identification of a cellular hierarchy and heterogeneity in mammary stem cells has given new clues that better explain breast tumor heterogeneity; explicitly proposing that different types of progenitor cells can give rise to different types of breast cancer stem cells which in turn outgrow and give rise to many different cancers. Imbalance in different putative stem cell populations of the breast was found to correlate with tumor progression.

\section{Conflict of Interest}

The author also certifies that there is no conflict of interest with any financial organization regarding the material discussed in the paper.

\section{References}

1. Clarke CA, Keegan TH, Yang J, Press DJ, Kurian AW, et al. (2012) AgeSpecific Incidence of Breast Cancer Subtypes: Understanding the Black-White Crossover. J Natl Cancer Inst 104(14): 1094-1101.

2. Parkin DM (2001) Global Cancer Statistics in the Year 2000. Lancet Oncol 2(9): 533-543.

3. Pharoah PD, Day NE, Duffy S, Easton DF, Ponder BA, et al. (1997) Family History and the Risk of Breast Cancer: A Systematic Review and MetaAnalysis. Int J Cancer 71(5): 800-809.

4. Colditz GA, Willett WC, Hunter DJ, Stampfer MJ, Manson JE, et al. (1993) Family History, Age, and Risk of Breast Cancer. Prospective Data from the Nurses' Health Study. JAMA 270(13): 338-343.

5. Johnson N, Lancaster T, Fuller A, Hodgson SV (1995) The Prevalence of a Family History of Cancer in General Practice. Family Practice 12(3): 287-289.

6. Lenz ER, Pugh LC, Milligan RA, Gift A, Suppe F, et al. (1997) The MiddleRange Theory of Unpleasant Symptoms: An Update. ANS Adv Nurs Sci 19(3): 14-27.

7. Dodd MJ, Miaskowski C, Lee KA (2004) Occurrence of Symptom Clusters. JNCI Monographs 32: 76-78.

8. Johnson NE (2006) Young Women's Perceptions of Breast Cancer. La Trobe University, Australia.

9. Michael B, Christobel S, Sheena M (1994) Breast Cancer: A Guide for Every Woman. Oxford University Press, USA.

10. McPherson K, CaMa S, Dixon JM (2000) Abc of Breast Diseases: Breast Cancer-Epidemiology, Risk Factors, and Genetics. BMJ 321(7261): 624.

11. Dimitrios T, MacMahon B, Philip C (1972) Menopause and Breast Cancer Risk. Journal of the National Cancer Institute 48(3): 605-613.

12. Kampert JB, Whittemore AS, Paffenbarger RS (1988) Combined Effect of Childbearing, Menstrual Events, and Body Size on Age-Specific Breast Cancer Risk. Am J Epidemiol 128(5): 962-979. 
13. Bernstein L (2002) Epidemiology of Endocrine-Related Risk Factors for Breast Cancer. J Mammary Gland Biol Neoplasia 7(1): 3-15.

14. MacMahon B, Cole P, Lin TM, Lowe CR, Mirra AP, et al. (1970) Age at First Birth and Breast Cancer Risk. Bull World Health Organ 43(2): 209-221.

15. Calle EE, Martin LM, Thun MJ, Miracle HL, Heath CW, et al. (1993) Family History, Age, and Risk of Fatal Breast Cancer. Am J Epidemiol 138(9): 675-681.

16. Foxcroft LM, Evans EB, Porter AJ (2004) The Diagnosis of Breast Cancer in Women Younger Than 40." The breast 13(4): 297-306.

17. Dite GS, Jenkins MA, Southey MC, Hocking JS, Giles GG, et al. (2003) Familial Risks, Early-Onset Breast Cancer, and Brca1 and Brca2 Germline Mutations. J Natl Cancer Inst 95(6): 448-457.

18. Williams T, Valerie C, Borland R (2001) Effects of Message Framing on Breast-Cancer-Related Beliefs and Behaviors: The Role of Mediating Factors. Journal of Applied Social Psychology 31(5): 925-950.

19. Williams, T, Clarke VA, Savage S (2002) Women's Perceptions of Familial Aspects of Breast Cancer. Health education 102(2): 50-59.

20. Saslow D, Hannan J, Osuch J, Alciati MH, Baines C, et al. (2004) Clinical Breast Examination: Practical Recommendations for Optimizing Performance and Reporting. CA Cancer J Clin 54(6): 327-344.

21. Harvey JA, Nicholson BT, Cohen MA (2008) Finding Early Invasive Breast Cancers: A Practical Approach. Radiology 248(1): 61-76.

22. Berg WA, Blume JD, Cormack JB, Mendelson EB, Lehrer D, et al. (2008) Combined Screening with Ultrasound and Mammography Vs Mammography Alone in Women at Elevated Risk of Breast Cancer. Jama 299(18): 2151-2163.

23. Senkus E, Kyriakides S, Ohno S, Penault-Llorca F, Poortmans P, et al (2010) Primary Breast Cancer: Esmo Clinical Practice Guidelines for Diagnosis, Treatment and Follow-Up. Ann Oncol 21(suppl_5): v8-v30.

24. Hartmann LC, Sellers TA, Frost MH, Lingle WL, Degnim AC, et al. (2005) Benign Breast Disease and the Risk of Breast Cancer. N Engl J Med 353(3): 229-237.

25. Onitilo AA, Engel JM, Greenlee RT, Mukesh BN (2009) Breast Cancer Subtypes Based on Er/Pr and Her2 Expression: Comparison of Clinicopathologic Features and Survival. Clin Med Res 7(1-2): 4-13.

26. Sørlie T, Perou CM, Tibshirani R, Aas T, Geisler S, et al. (2001) Gene Expression Patterns of Breast Carcinomas Distinguish Tumor Subclasses with Clinical Implications. Proc Natl Acad Sci U S A 98(19): 10869-10874.

27. Slamon DJ (1987) Proto-Oncogenes and Human Cancers. N Engl J Med 317(15): 955-957.

28. Ross JS, Fletcher JA, Bloom KJ, Linette GP, Stec J, et al. (2004) Targeted Therapy in Breast Cancer the Her-2/Neu Gene and Protein. Mol Cell Proteomics 3(4): 379-398.

29. Ross JS, Fletcher JA, Linette GP, Stec J, Clark E, et al. (2003) The Her-2/ Neu Gene and Protein in Breast Cancer 2003: Biomarker and Target of Therapy. oncologist 8(4): 307-325.

30. Blows FM, Driver KE, Schmidt MK, Broeks A, van Leeuwen FE, et al (2010) Subtyping of Breast Cancer by Immunohistochemistry to Investigate a Relationship between Subtype and Short and Long Term Survival: A Collaborative Analysis of Data for 10,159 Cases from 12 Studies. PLoS med 7(5): e1000279.

31. Rimawi MF, Shetty PB, Weiss HL, Schiff R, Osborne CK, et al. (2010) Epidermal Growth Factor Receptor Expression in Breast Cancer Association with Biologic Phenotype and Clinical Outcomes. Cancer 116(5): 1234-1242.
32. Giuliano AE, Kirgan DM, Guenther JM, Morton DL (1994) Lymphatic Mapping and Sentinel Lymphadenectomy for Breast Cancer. Annals of surgery 220(3): 391-398.

33. Chen SL, Iddings DM, Scheri RP, Bilchik AJ (2006) Lymphatic Mapping and Sentinel Node Analysis: Current Concepts and Applications. CA: a cancer journal for clinicians 56(5): 292-309.

34. Veronesi U, Banfi A, Salvadori B, Luini A, Saccozzi R, et al. (1990) Breast Conservation Is the Treatment of Choice in Small Breast Cancer: LongTerm Results of a Randomized Trial. Eur J Cancer 26(6): 668-670.

35. Toth BA, Lappert P (1991) Modified Skin Incisions for Mastectomy: The Need for Plastic Surgical Input in Preoperative Planning. Plast Reconstr Surg 87(6): 1048-1053.

36. Carlson GW (1996) Skin Sparing Mastectomy: Anatomic and Technical Considerations. Am Surg 62(2): 151-155.

37. Fisher B, Anderson S, Redmond CK, Wolmark N, Wickerham DL, et al. (1995) Reanalysis and Results after 12 Years of Follow-up in a Randomized Clinical Trial Comparing Total Mastectomy with Lumpectomy with or without Irradiation in the Treatment of Breast Cancer. N Engl J Med 333(22): 1456-1461.

38. Sioshansi S, Ehdaivand S, Cramer C, Lomme MM, Price LL, et al. (2012) Triple Negative Breast Cancer Is Associated with an Increased Risk of Residual Invasive Carcinoma after Lumpectomy. Cancer 118(16): 3893-3898.

39. Veronesi U, Cascinelli N, Mariani L, Greco M, Saccozzi R, et al. (2002) Twenty-Year Follow-up of a Randomized Study Comparing BreastConserving Surgery with Radical Mastectomy for Early Breast Cancer. New England Journal of Medicine 347(16): 1227-1232.

40. Arriagada R, Lê MG, Rochard F, Contesso G (1996) Conservative Treatment Versus Mastectomy in Early Breast Cancer: Patterns of Failure with 15 Years of Follow-up Data. Institut Gustave-Roussy Breast Cancer Group. J Clin Oncol 14(5): 1558-1564.

41. Albert JM, Pan IW, Shih YC, Jiang J, Buchholz TA, et al. (2012) Effectiveness of Radiation for Prevention of Mastectomy in Older Breast Cancer Patients Treated with Conservative Surgery. Cancer 118(19): 4642-4651.

42. Burstein HJ, Bellon JR, Galper S, Lu HM, Kuter I, et al. (2006) Prospective Evaluation of Concurrent Paclitaxel and Radiation Therapy after Adjuvant Doxorubicin and Cyclophosphamide Chemotherapy for Stage Ii or Iii Breast Cancer. Int J Radiat Oncol Biol Phys 64(2): 496-504.

43. Goldhirsch A, Glick JH, Gelber RD, Coates AS, Thürlimann B, et al. (2005) Meeting Highlights: International Expert Consensus on the Primary Therapy of Early Breast Cancer 2005. Annals of Oncology 16(10): 1569-1583.

44. Harris EE, Christensen VJ, Hwang WT, Fox K, Solin LJ, et al. (2005) Impact of Concurrent Versus Sequential Tamoxifen with Radiation Therapy in Early-Stage Breast Cancer Patients Undergoing Breast Conservation Treatment. J Clin Oncol 23(1): 11-16.

45. Russo J, Russo IH (2006) The Role of Estrogen in the Initiation of Breast Cancer. J Steroid Biochem Mol Biol 102(1-5): 89-96.

46. Olson JA, Budd GT, Carey LA, Harris LA, Esserman LJ, et al. (2009) Improved Surgical Outcomes for Breast Cancer Patients Receiving Neoadjuvant Aromatase Inhibitor Therapy: Results from a Multicenter Phase Ii Trial. J Am Coll Surg 208(5): 906-914.

47. Preece PE, Wood RA, Mackie CR, Cuschieri A (1982) Tamoxifen as Initial Sole Treatment of Localised Breast Cancer in Elderly Women: A Pilot Study. Br Med J (Clin Res Ed) 284(6319): 869-870.

48. Fisher B, Costantino JP, Wickerham DL, Redmond CK, Kavanah M, et al. (1998) Tamoxifen for Prevention of Breast Cancer: Report of the 
National Surgical Adjuvant Breast and Bowel Project P-1 Study. J Natl Cancer Inst 90(18): 1371-1388.

49. Cole MP, Jones CT, Todd ID (1971) A New Anti-Oestrogenic Agent in Late Breast Cancer: An Early Clinical Appraisal of Ici46474. Br J Cancer 25(2): 270-275.

50. Davies C, Godwin J, Gray R, Clarke M, Cutter D, et al. (2011) Relevance of Breast Cancer Hormone Receptors and Other Factors to the Efficacy of Adjuvant Tamoxifen: Patient-Level Meta-Analysis of Randomised Trials. Lancet 378(9793): 771-784.

51. Anthony H (2000) Ici 182,780 (Faslodex ${ }^{\mathrm{TM}}$ ). Cancer 89(4): 817-825.

52. Howell A, Robertson JF, Abram P, Lichinitser MR, Elledge R, et al. (2004) Comparison of Fulvestrant Versus Tamoxifen for the Treatment of Advanced Breast Cancer in Postmenopausal Women Previously Untreated with Endocrine Therapy: A Multinational, Double-Blind, Randomized Trial. J Clin Oncol 22(9): 1605-1613.

53. Howell A, Robertson JF, Quaresma AJ, Aschermannova A, Mauriac L, et al. (2002) Fulvestrant, Formerly Ici 182,780, Is as Effective as Anastrozole in Postmenopausal Women with Advanced Breast Cancer Progressing after Prior Endocrine Treatment. J Clin Oncol 20(16): 3396-3403.

54. Njar VC, Brodie AM (1999) Comprehensive Pharmacology and Clinical Efficacy of Aromatase Inhibitors. Drugs 58(2): 233-255.

55. Campos SM (2004) Aromatase Inhibitors for Breast Cancer in Postmenopausal Women. The oncologist 9(2): 126-136.

56. Howell A, Cuzick J, Baum M, Buzdar A, Dowsett M, et al. (2005) Results of the Atac (Arimidex, Tamoxifen, Alone or in Combination) Trial after Completion of 5 Years' Adjuvant Treatment for Breast Cancer. Lancet 365(9453): 60-62.

57. Burstein HJ, Prestrud AA, Seidenfeld J, Anderson H, Buchholz TA, et al. (2010) American Society of Clinical Oncology Clinical Practice Guideline Update on Adjuvant Endocrine Therapy for Women with Hormone Receptor-Positive Breast Cancer. J Clin Oncol 28(23): 3784 3796.

58. Shou J, Massarweh S, Osborne CK (2004) Mechanisms of Tamoxifen Resistance: Increased Estrogen Receptor-Her2/Neu Cross-Talk in Er/ Her2-Positive Breast Cancer. J Natl Cancer Inst 96(12): 926-935.

59. Arpino G, Wiechmann L, Osborne CK, Schiff R (2008) Crosstalk between the Estrogen Receptor and the Her Tyrosine Kinase Receptor Family: Molecular Mechanism and Clinical Implications for Endocrine Therapy Resistance. Endocrine reviews 29(2): 217-233.

60. Kunisue H, Kurebayashi J, Otsuki T, Tang CK, Kurosumi M, et al. (2000) Anti-Her2 Antibody Enhances the Growth Inhibitory Effect of AntiOestrogen on Breast Cancer Cells Expressing Both Oestrogen Receptors and Her2. Br J Cancer 82(1): 46-51.

61. Witters LM, Kumar R, Chinchilli VM, Lipton A (1997) Enhanced AntiProliferative Activity of the Combination of Tamoxifen Plus Her-2-Neu Antibody. Breast Cancer Res Treat 42(1): 1-5.

62. Baselga J, Campone M, Piccart M, Burris HA, Rugo HS, et al. (2012) Everolimus in Postmenopausal Hormone-Receptor-Positive Advanced Breast Cancer. N Engl J Med 366(6): 520-529.
63. Cortazar P, Justice R, Johnson J, Sridhara R, Keegan P, et al. (2012) Us Food and Drug Administration Approval Overview in Metastatic Breast Cancer. J Clin Oncol 30(14): 1705-1711.

64. Water VDW, Markopoulos C, Velde VDCJ, Seynaeve C, Hasenburg A, et al. (2012) Association between Age at Diagnosis and Disease-Specific Mortality among Postmenopausal Women with Hormone ReceptorPositive Breast Cancer. Jama 307(6): 590-597.

65. Cardoso F, Harbeck N, Fallowfield L, Kyriakides S, Senkus E, et al (2010) Locally Recurrent or Metastatic Breast Cancer: Esmo Clinical Practice Guidelines for Diagnosis, Treatment and Follow-Up. Ann Oncol 21(suppl_5): v11-v19.

66. Slamon DJ, Leyland-Jones B, Shak S, Fuchs H, Paton V, et al. (2001) Use of Chemotherapy Plus a Monoclonal Antibody against Her2 for Metastatic Breast Cancer That Overexpresses Her2. N Engl J Med 344(11): 783-792.

67. Roy V, Pockaj BA, Allred JB, Apsey H, Northfelt DW, et al. (2013) A Phase Ii Trial of Docetaxel and Carboplatin Administered Every Two Weeks as Preoperative Therapy for Stage Ii or Iii Breast Cancer: Ncctg Study N0338. Am J Clin Oncol 36(6): 540-544.

68. Paik S, Tang G, Shak S, Kim C, Baker J, et al. (2006) Gene Expression and Benefit of Chemotherapy in Women with Node-Negative, Estrogen Receptor-Positive Breast Cancer. J Clin Oncol 24(23): 3726-3734.

69. Vanneman M, Dranoff G (2012) Combining Immunotherapy and Targeted Therapies in Cancer Treatment. Nat Rev Cancer 12(4): $237-$ 251.

70. Baselga J, Tripathy D, Mendelsohn J, Baughman S, Benz CC, et al. (1999) Phase Ii Study of Weekly Intravenous Trastuzumab (Herceptin) in Patients with Her2/Neu-Overexpressing Metastatic Breast Cancer. Semin Oncol 26(4 Sippl): 78-83.

71. Valachis A, Nearchou A, Lind P, Mauri D (2012) Lapatinib, Trastuzumab or the Combination Added to Preoperative Chemotherapy for Breast Cancer: A Meta-Analysis of Randomized Evidence. Breast Cancer Res Treat 135(3): 655-662.

72. Katherine S (2013) Women's Experiences of Breast Cancer: A Longitudinal Perspective.

73. Haraguchi N, Ishii H, Mimori K, Tanaka F, Ohkuma M, et al. (2010) Cd13 Is a Therapeutic Target in Human Liver Cancer Stem Cells. J Clin Invest 120(9): 3326-3339.

74. Bao S, Wu Q McLendon RE, Hao Y, Shi Q et al. (2006) Glioma Stem Cells Promote Radioresistance by Preferential Activation of the DNA Damage Response. Nature 444(7120): 756-760.

75. Charafe-Jauffret E, Ginestier C, Birnbaum D (2009) Breast Cancer Stem Cells: Tools and Models to Rely On. BMC cancer 9(1): 202.

76. Cobaleda C, Cruz JJ, González-Sarmiento R, Sánchez-García I, PérezLosada J, et al. (2008) The Emerging Picture of Human Breast Cancer as a Stem Cell-Based Disease. Stem cell reviews 4(2): 67-79. 
(C) Commons Attribution 4.0 License DOI: 10.19080/JGWH.2019.16.555935

\section{Your next submission with Juniper Publishers} will reach you the below assets

- Quality Editorial service

- Swift Peer Review

- Reprints availability

- E-prints Service

- Manuscript Podcast for convenient understanding

- Global attainment for your research

- Manuscript accessibility in different formats

( Pdf, E-pub, Full Tsext, Audio)

- Unceasing customer service

Track the below URL for one-step submission https://juniperpublishers.com/online-submission.php 